\title{
Studies on the preparation of lead(II) chloride from galvanizing plant wastes
}

\author{
M. M. Rahman ${ }^{a *}$, A. J. M. T. Neger ${ }^{a}$, A Gafur ${ }^{a}$ and A. S. W. Kurny \\ ${ }^{a}$ Bangladesh Council of Scientific and Industrial Research \\ ${ }^{b}$ Bangladesh University of Engineering and Technology, Dhaka, Bangladesh.
}

\begin{abstract}
Galvanizing plant wastes containing $71.82 \%$ lead was leached in hydrochloric acid. Lead was precipitated from the leach liquor as lead chloride and purified by recrystallisation. The process parameters like concentration of hydrochloric acid, time of leaching, mode of reaction, number of re-crystallization etc. were optimised. Nearly $70 \%$ of lead contained by the waste material could be leached out and converted to lead(II) chloride. The product $\left(\mathrm{PbCl}_{2}\right)$ was characterised by atomic absorption spectroscopy, thermogravimetric analysis, $\mathrm{x}$-ray diffraction analysis, and scanning electron microscopy. Atomic absorption spectroscopic analysis showed that the product was $93 \%$ pure. X-ray diffraction analysis confirmed that the product possess cotunnite phase having orthorhombic structure. The needle like shape of the prepared $\mathrm{PbCl}_{2}$ crystal was confirmed by scanning electron microscopy. Physical properties like melting point and density were also very close to those reported in literature.
\end{abstract}

Keywords: Galvanizing plant wastes; Acid-leaching; Lead(II) chloride; Re-crystallization

\section{Introduction}

Galvanization is a process of coating iron and steel with a thin layer of zinc by passing the metal through a molten bath of zinc at a temperature of around $460^{\circ} \mathrm{C}$. In such galvanizing processes lead is used to improve the fluidity of the bath, enhance drainage properties and thus limit excess zinc on the dipped product (Lohse et al., 2008). Lead also protects the bottom of steel baths used to hold the molten zinc against corrosion through the formation of $\mathrm{Zn} / \mathrm{Fe}$ alloy. Lead wets steel so that final zinc coat is strongly adhering to the steel and gives sparkle to the finished galvanized work.

In Bangladesh 6-10 percent of zinc used for galvanizing is wasted in the form of dross and ash. Solid dross settles on top of molten lead at the bottom of the bath and is removed periodically. Removed dross contains both soluble lead and mechanically trapped lead.

A significant quantity of lead is thus wasted in the form of galvanizing plant wastes. Recycling or recovery of value materials from these wastes can be economically rewarding. At the same time utilization of such wastes will help reduce environmental pollution due to such wastes.

Lead(II) chloride $\left(\mathrm{PbCl}_{2}\right)$ forms white crystalline precipitate or white silky rhombic needles (Thorpe's Dictionary). It occurs naturally in the form of mineral cotunnite
(Wilkipedia). It is colorless, with a density of $5.3-5.8 \mathrm{~g} / \mathrm{cm}^{3}$. The hardness on the Mohs scale is 1.5-2. Its melting and boiling points are $501{ }^{\circ} \mathrm{C}$ and $950{ }^{\circ} \mathrm{C}$ respectively (Encyclopedia). The crystal structure is orthorhombic (Perry \& Phillips, 1995). It is poorly soluble in cold water but sparingly soluble in hot water. The solubility of lead(II) chloride is 0.99 percent at $20{ }^{\circ} \mathrm{C}$ and 3.34 percent at $100{ }^{\circ} \mathrm{C}$ (Robert C. Weast). It also possesses high birefringence, low attenuation coefficient, wide transparency range and good mechanical properties (Nisha, 2008).

Lead(II) chloride is one of the most important lead-based laboratory reagents. It is the starting material as a precursor for a number of organolead compounds. It has been used in asbestos clutch or brake linings, as a co-catalyst for acrylonitrile production, as a catalyst for polymerization of olefins to highly crystalline stereoregular polymers, as a cathode for magnesium-lead dichloride seawater-activatable batteries, to make rectifying junctions on gallium arsenide, as a flame retardant in polycarbonates and nylon-6,6 wire coatings, as a flux for the galvanizing of steel, expanding polymer-based morter, as a solid-phase chemical scrubber for ozone and hydrogen sulfide removal from gas, as a photochemical-sensitizing agent for metal patterns on printed circuit boards, as a sterilization indicator on tapes that darken with zinc sulfide 
at $121{ }^{\circ} \mathrm{C}$ in moist air, sound insulating rubber sealant and corrosion inhibitor for galvanizing steel (Ullmann's encyclopedia and Encyclopedia of chemical technology). $\mathrm{PbCl}_{2}$ is used in production of infrared transmitting glass for carbon dioxide lasers (Perry \& Phillips, 1995) and ornamental glass called aurena glass. A basic chloride of lead, $\mathrm{PbCl}_{2}$. $\mathrm{Pb}(\mathrm{OH})_{2}$, is known as Patteson's white lead and is used as pigment in white paint (Perry \& Phillips,1995). Lead(II) chloride crystals are acousto-optical materials play an important role in acousto optic devices as acousto optic modulators (P. Nisha, 2008). It has a high figure of merit approximately ten times greater than that of lead molybdate, which is an efficient acousto-optical material.

There are several methods for the preparation of lead chloride (Thorpe's Dictionary, Ullmans Encyclopedia of Chemical Technology, M. Abdul Khadar and M.A. Ittyachen, 1980 and P. Sagayaraj, 1995). But all these methods use pure oxide or salt of lead as lead source.

This paper discusses the preparation of lead(II) chloride crystals from the galvanizing plant waste materials and hydrochloric acid. To the best of our knowledge, no such work has so far been reported.

\section{Materials and methods}

The galvanizing plant waste was collected from one galvanizing plant located at Chittagong, Bangladesh. Analytical grade hydrochloric acid (Merck, Germany) used in these experiments was collected from local market. The analytical result on the waste material and $\mathrm{HCl}$ used are given in Table I.

Table I. Assay of galvanizing plant waste and hydrochloric acid

\begin{tabular}{lll}
\hline Name of materials & Parameters & Percent \\
\hline Zinc dross & Lead & 71.82 \\
& Zinc & 27.66 \\
& Iron & 0.17 \\
\hline $\mathrm{HCl}$ & $\mathrm{HCl}$ & 34.76 \\
\hline
\end{tabular}

\section{Experimental procedure}

The galvanizing plant waste was leached in hydrochloric acid for a certain period of time at a fixed temperature. The leach liquor was filtered and concentrated to such a point that precipitation begins on cooling. The precipitates were filtered, washed with cold water and re-crystallized with hot water. It was then allowed to dry at $100{ }^{\circ} \mathrm{C}$ in an oven to a constant weight.

A replacement reaction takes place during leaching as hydrogen is above lead in the reaction series. The reaction is simple, slow and may be represented as follows:

$\mathrm{Pb}+2 \mathrm{HCl} \longrightarrow \mathrm{PbCl}_{2}+\mathrm{H}_{2}$

Four sets of experiments were performed. The effects of reaction parameters like (i) concentration of acid, (ii) mode of reaction, (iii) period of reaction time and (iv) number of re-crystallization were investigated. In each experiment approximately $10 \mathrm{~g}$ of galvanizing plant waste was allowed to react with $10 \mathrm{~mL} \mathrm{35 \%} \mathrm{hydrochloric} \mathrm{acid} \mathrm{(the} \mathrm{latter} \mathrm{was}$ diluted to different concentrations) at a fixed temperature for different periods of time. The product in each case was purified, separated, dried and analyzed.

Atomic Absorption Spectroscopic analysis

Quantitative analyses of the waste material and prepared products were carried out by atomic absorption spectroscopy (AAS, Instrument: VARIAN, AA 240 FS, Australia).

\section{X-ray Diffraction analysis}

The phase composition of the prepared lead(II) chloride was determined by $\mathrm{x}$-ray diffraction analysis. A BRUKER X-ray Diffiactometer model 'Advanced D8' was used to record the diffraction patterns using a $\mathrm{CuK}_{a}$ radiation $(\lambda=1.5406 \AA)$. The diffraction patterns were recorded in the range 15-70 degrees with scanning speed 2 degree/minute. Phase analysis was performed by comparing the $\mathrm{d}$ values and intensity ratios of the diffraction lines in the recorded pattern with data in the PDF file [PDF file 00-026-1150].

\section{Scanning Electron Microscopy}

Morphological analysis of the prepared lead(II) chloride was carried out on a 2600SN Hitachi (Japan) Scanning Electron Microscope (SEM) equipped with Germanian detector and Diamond window. The sample was mounted using double sided tape.

\section{TG/DTA/DTG analysis}

TG/DTA 6300 (Model-EXSTAR 6000, SII, Seiko Instrument Inc.) was used to evaluate the thermal behaviors of the sample. The thermogravimetric and differential thermal analyses (TG/DTA) were carried out in nitrogen atmos- 
phere at a heating rate of $20 \% \mathrm{~min}$. The temperature difference between an inert (Alumina) reference and the sample was recorded and mass loss was calculated from the thermogravimetric curve.

\section{Results and discussion}

Lead could be separated in the form of lead(II) chloride from galvanizing plant waste containing 71.82 percent lead. In the preparation of lead(II) chloride, effects of different parameters on the extent of yield were studied. Table II shows the effect of concentration of hydrochloric acid on percent yield. The experiments of this series were carried out at $80^{\circ} \mathrm{C}$, with $10 \mathrm{~mL}$ conc. hydrochloric acid for $10 \mathrm{hrs}$ of reaction period in an open beaker. $1.13 \mathrm{M}, 1.69 \mathrm{M}, 2.26 \mathrm{M}$ and $2.82 \mathrm{M}$ hydrochloric acid were used in this series of experiments. Stirring was continued, keeping the volume fixed by adding water periodically. The difference in percent yield for different acid concentrations was very poor, yet experiment 3 (2.26 $\mathrm{M}$ hydrochloric acid) produced the best yield of around 53 percent. The percent yield is calculated as $\mathrm{H}=(\mathrm{G} / \mathrm{E} \mathrm{x}$ $0.7182 \times 1.3422) \times 100$, where 0.7182 is the conversion factor of lead content in dross and 1.3422 is the conversion factor of lead conversion to lead chloride. of this series were carried out at $80{ }^{\circ} \mathrm{C}$, with $10 \mathrm{~mL} 2.26 \mathrm{M}$ hydrochloric acid for a reaction period of $10 \mathrm{hrs}$. It can be seen that the closed system gave a higher percent yield. It may be attributed to the fact that, in the open system some chloride ion evaporated out with water vapor making a lesser amount of chloride ion available for the reaction.

The effect of time of reaction on the percent yield is depicted in Table IV. The experiments were conducted for 5,10 , 15,20 and $25 \mathrm{hrs}$ at $80^{\circ} \mathrm{C}$, with $10 \mathrm{~mL} 2.26 \mathrm{M}$ hydrochloric acid in a closed system with constant stirring. It can be seen that a reaction period of $20 \mathrm{hrs}$ gave the highest percent yield. However, the difference in percent yield among the experiments of this series is very nominal except experiment no. 7, where reaction was carried out only for $5 \mathrm{hrs}$. Therefore, from the view point of economy, $10 \mathrm{hrs}$ of reaction period was considered to be the optimum.

Table V shows the effect of time of crystallization on the percent yield of lead(II) chloride. Four experiments were carried out with 2, 3, 4 and 5 times re-crystallization keeping all other reaction conditions same. It can be seen that percent yield declined with an increase in the number of re-crystallization.

Table II. Effect of concentration of hydrochloric acid in the preparation of lead(II) chloride

\begin{tabular}{lccccccc}
\hline $\begin{array}{l}\text { No. of Expt. } \\
\text { (A) }\end{array}$ & $\begin{array}{c}\text { Amount of } \\
\text { zinc dross } \\
\text { taken in g (B) }\end{array}$ & $\begin{array}{c}\text { Concentration } \\
\text { of acid in } \\
\text { molar (C) }\end{array}$ & $\begin{array}{c}\text { Un-reacted } \\
\text { zinc dross in g } \\
\text { (D) }\end{array}$ & $\begin{array}{c}\text { Reacted zinc } \\
\text { dross in g (E) }\end{array}$ & $\begin{array}{c}\text { Lead content } \\
\text { in reacted } \\
\text { mass in g (F) }\end{array}$ & $\begin{array}{c}\text { Amount of } \\
\text { product in g } \\
\text { (G) }\end{array}$ & $\begin{array}{c}\text { Percent Yield } \\
(\mathrm{H})\end{array}$ \\
\hline 01 & 10.0020 & 1.13 & 4.1366 & 5.8654 & 4.2125 & 2.7974 & 49.48 \\
02 & 10.3760 & 1.69 & 3.7210 & 6.6550 & 4.7796 & 3.3770 & 52.64 \\
03 & 10.0266 & 2.26 & 3.7758 & 6.2508 & 4.4893 & 3.1978 & 53.07 \\
04 & 10.0176 & 2.82 & 3.6838 & 6.3338 & 4.5489 & 3.0964 & 52.37 \\
\hline
\end{tabular}

Conditions: Temperature $-80^{\circ} \mathrm{C}$, Amount of conc. acid - $10 \mathrm{~mL}$, Time - $10 \mathrm{hrs}$, Mode of reaction - Open

Table III depicts the effect of mode of reaction. Experiment 5 was carried out in an open beaker and the volume of the leaching solution was kept constant by periodically adding water to the beaker. Experiment 6 was conducted in a closed system in which the volume of the leaching solution was kept constant by using a reflux condenser. The experiments
The purity of the prepared sample was only around 90 percent whereas the standard sample was 99.08 percent pure (Table VI). The purity of the prepared sample could be increased to 93.46 percent by increasing the number of recrystallization. Zinc chloride content of the sample prepared by a single re-crystallization was around 6.981 percent and

Table III. Effect of mode of reaction in the preparation of lead(II) chloride

\begin{tabular}{lccccccc}
\hline No. of Expt. & $\begin{array}{c}\text { Amount of zinc } \\
\text { dross taken, } \mathrm{g}\end{array}$ & $\begin{array}{c}\text { Mode of reac- } \\
\text { tion }\end{array}$ & $\begin{array}{c}\text { Un-reacted } \\
\text { zinc dross, g }\end{array}$ & $\begin{array}{c}\text { Reacted zinc } \\
\text { dross, g }\end{array}$ & $\begin{array}{c}\text { Lead content in } \\
\text { reacted mass, g }\end{array}$ & $\begin{array}{c}\text { Amount of } \\
\text { product, } \mathrm{g}\end{array}$ & Percent Yield \\
\hline 05 & 10.0025 & Open & 3.7775 & 6.2250 & 4.4708 & 3.1872 & 53.12 \\
06 & 10.0760 & Closed & 3.3962 & 6.6798 & 4.7974 & 3.8879 & 60.38 \\
\hline
\end{tabular}

Conditions: Temperature- $80^{\circ} \mathrm{C}$, Amount of conc. acid-10 mL, Concentration of acid-2.26 M, Time-10 hrs 
Table IV. Effect of reaction time in the preparation of lead(II) chloride

\begin{tabular}{lccccccc}
\hline No. of Expt. & $\begin{array}{c}\text { Amount of zinc } \\
\text { dross taken, }\end{array}$ & $\begin{array}{c}\text { Reaction time, } \\
\mathrm{hr}\end{array}$ & $\begin{array}{c}\text { Un-reacted } \\
\text { zinc dross, g }\end{array}$ & $\begin{array}{c}\text { Reacted zinc } \\
\text { dross, g }\end{array}$ & $\begin{array}{c}\text { Lead content in } \\
\text { reacted mass, g }\end{array}$ & $\begin{array}{c}\text { Amount of } \\
\text { product, } \mathrm{g}\end{array}$ & Percent Yield \\
\hline 07 & 10.0001 & 05 & 5.7947 & 4.2054 & 3.0203 & 0.4741 & 11.70 \\
08 & 10.0044 & 10 & 3.2982 & 6.7062 & 4.8164 & 3.9304 & 60.80 \\
09 & 10.1742 & 15 & 3.3301 & 6.8441 & 4.9154 & 4.0112 & 62.05 \\
10 & 10.0234 & 20 & 3.0634 & 6.9599 & 4.9986 & 4.0791 & 63.10 \\
11 & 10.0712 & 25 & 3.1945 & 6.9224 & 4.9717 & 4.0571 & 62.76 \\
\hline
\end{tabular}

Conditions :Temp: $80^{\circ} \mathrm{C}$, Amount of conc. acid: $10 \mathrm{~mL}$, Conc. of acid: $2.26 \mathrm{M}$, Mode of reaction: closed

Table V. Effect of number of re-crystallization on yield of lead(II) chloride

\begin{tabular}{lccccccc}
\hline No. of Expt. & $\begin{array}{c}\text { Amount of } \\
\text { waste, g }\end{array}$ & $\begin{array}{c}\text { Numbers of re- } \\
\text { crystallization }\end{array}$ & $\begin{array}{c}\text { Un-reacted } \\
\text { zinc dross, g }\end{array}$ & $\begin{array}{c}\text { Reacted zinc } \\
\text { dross, g }\end{array}$ & $\begin{array}{c}\text { Lead content in } \\
\text { reacted mass, g }\end{array}$ & $\begin{array}{c}\text { Amount of } \\
\text { product, g }\end{array}$ & Percent Yield \\
\hline 11 & 10.0048 & 2 & 3.2976 & 6.7072 & 4.8171 & 4.2142 & 65.18 \\
12 & 10.0742 & 3 & 3.3784 & 6.6958 & 4.8089 & 3.9274 & 60.85 \\
13 & 10.0238 & 4 & 3.3280 & 6.6958 & 4.8089 & 3.4915 & 54.09 \\
14 & 10.0702 & 5 & 3.3641 & 6.7061 & 4.8163 & 3.1107 & 48.12 \\
\hline
\end{tabular}

Conditions: Temp: $80{ }^{\circ} \mathrm{C}$, Amount of conc. acid: $10 \mathrm{~mL}$, Conc. of acid: $2.26 \mathrm{M}$, Mode of reaction: Closed

declined to 2.675 percent with an increase of number of recrystallization to 5 . The trend indicates that further re-crystallization would enhance the purity of the product. Iron content was nearly zero. Melting point, density, $\mathrm{pH}$ value and moisture content of the prepared samples were identical. The colour of the prepared sample was almost white except of sample no. 11, which was prepared by single re-crystallization. It becomes shiny white when number of re-crystallization was increased to 3 and 4. results in published literature (Nisha, 2008). From DTG curve, a single sharp peak was found at $745.2{ }^{\circ} \mathrm{C}$, which indicated that complete sublimation took place at this temperature. The DTA curve showed one endothermic and two exothermic peaks. The sharp endothermic peak observed at $494.5{ }^{\circ} \mathrm{C}$ corresponds to its melting point while the exothermic peaks at $498.1{ }^{\circ} \mathrm{C}$ and $751.1{ }^{\circ} \mathrm{C}$ correspond to evolution of chlorine and sublimation of $\mathrm{PbCl}_{2}$ according to the TG curve.

Table VI. Analytical and technical data on some prepared lead(II) chloride

\begin{tabular}{lcccccccc}
\hline $\begin{array}{c}\text { No. of } \\
\text { Sample }\end{array}$ & $\begin{array}{c}\text { lead(II) chlo- } \\
\text { ride, percent }\end{array}$ & $\begin{array}{c}\text { zinc chloride, } \\
\text { percent }\end{array}$ & Iron, ppm & $\begin{array}{c}\text { Melting } \\
\text { point, }{ }^{\circ} \mathrm{C}\end{array}$ & $\begin{array}{c}\text { Density, } \\
\mathrm{g} / \mathrm{cm}^{3}\end{array}$ & pH-value & Colour hue \\
\hline 11 & 89.15 & 6.981 & 12 & 494.4 & 5.72 & 3.98 & Red tinted white \\
12 & 90.38 & 5.405 & -- & 494.3 & 5.73 & 4.17 & White \\
13 & 92.04 & 4.013 & -- & 494.2 & 5.70 & 4.21 & Shiny white \\
14 & 93.46 & 2.675. & -- & 494.5 & 5.72 & 4.23 & Shiny white \\
Standard & 99.08 & nil & 08 & 501.0 & 5.85 & 4.20 & Bright white \\
\hline
\end{tabular}

Fig. 1 shows the (TG/DTA) curves of $\mathrm{PbCl}_{2}$. The prepared $\mathrm{PbCl}_{2}$ samples were found to be thermally stable up to $488^{\circ} \mathrm{C}$ and decomposition started at $488^{\circ} \mathrm{C}$. At $488^{\circ} \mathrm{C}$ breakdown took place and $0.7 \%$ mass was lost due to the evolution of chlorine. Sublimation of $\mathrm{PbCl}_{2}$ started at $676.2{ }^{\circ} \mathrm{C}$ with $1 \%$ mass loss. Then sharp declination took place. At $717.5^{\circ} \mathrm{C}$ and $743.7{ }^{\circ} \mathrm{C}$, mass loss of $48.7 \%$ and $74.2 \%$ respectively were recorded. At $800{ }^{\circ} \mathrm{C}, 3 \%$ of the original mass appeared as residue. The results obtained are in good agreement with the
$\mathrm{X}$-ray diffraction patterns recorded on the prepared $\mathrm{PbCl}_{2}$ sample (Fig. 2) contained many more diffraction lines than those recorded in the diffraction data file for lead chloride (PDF file 00-026-1150). Most of the diffraction lines correspond to the cotunnite $\left(\mathrm{PbCl}_{2}\right)$ phase with orthorhombic crystal structure having lattice parameters $a=7.6222, b=$ 9.0448, $c=4.5348$ Aand $\alpha=\beta=\gamma=90^{\circ}$. A slight shift in the positions of the diffraction lines could also be noted. Such shift in the diffraction lines is usual in a sample containing 


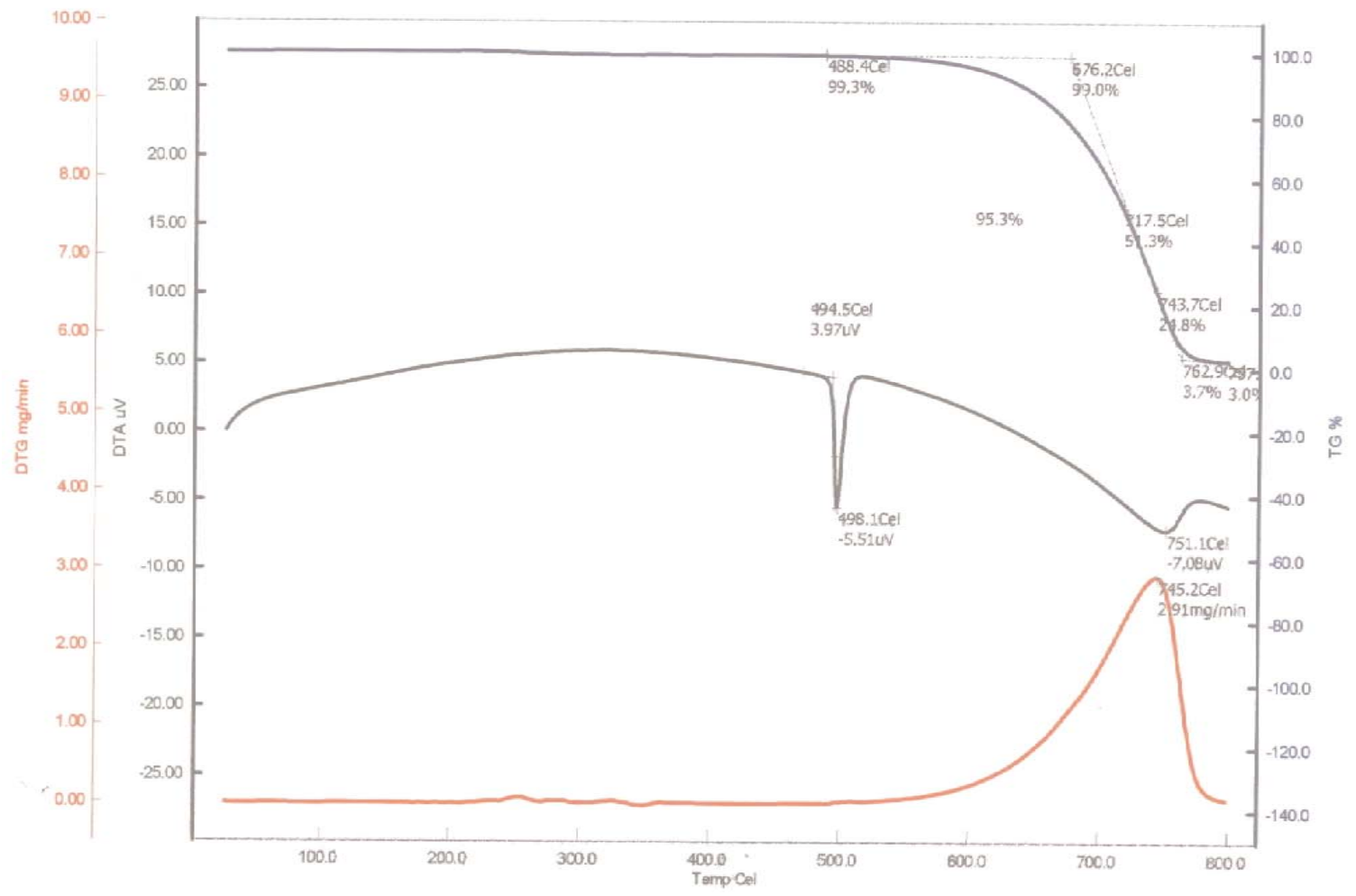

Fig. 1. TG/DTA pattern of lead(II) chloride of sample No 7

impurities. The additional diffraction lines belong to the impurity phases. It may be pointed out that the prepared sample contained 6.98 percent $\mathrm{ZnCl}_{2}$. The diffraction lines which matched well with those reported for the standard sample were from the planes of (020), (011), (120), (200), (111), (220), (211), (031), (002), (320), (311), (231), (212), (151), (402), (511), (260) and (071).
Morphological studies of lead(II) chloride were carried out by scanning electron microscopy (SEM) and a micrograph is shown in Fig. 3. A close comparison of this image with another image of lead(II) chloride at www.crt-journal.org reveals that the needle shape crystal of the prepared sample compares well with the images reported by others (Nisha, 2008).

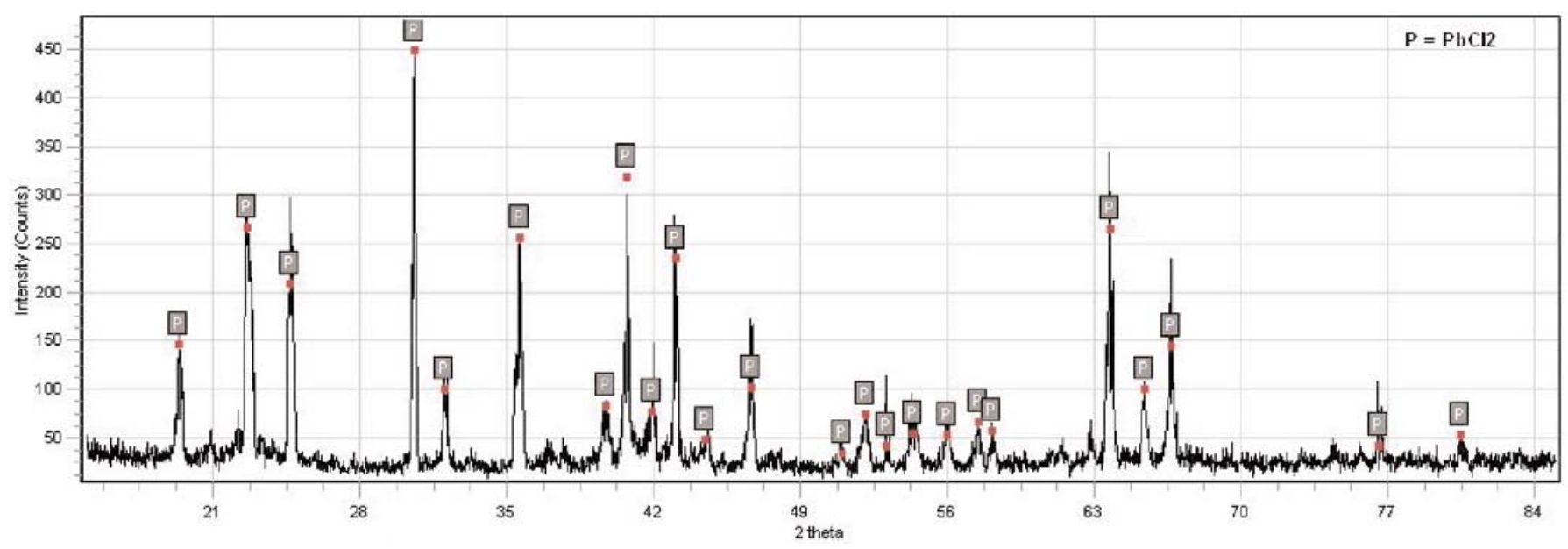

Fig. 2. XRD pattern of prepared lead(II) chloride (Sample No 8) 


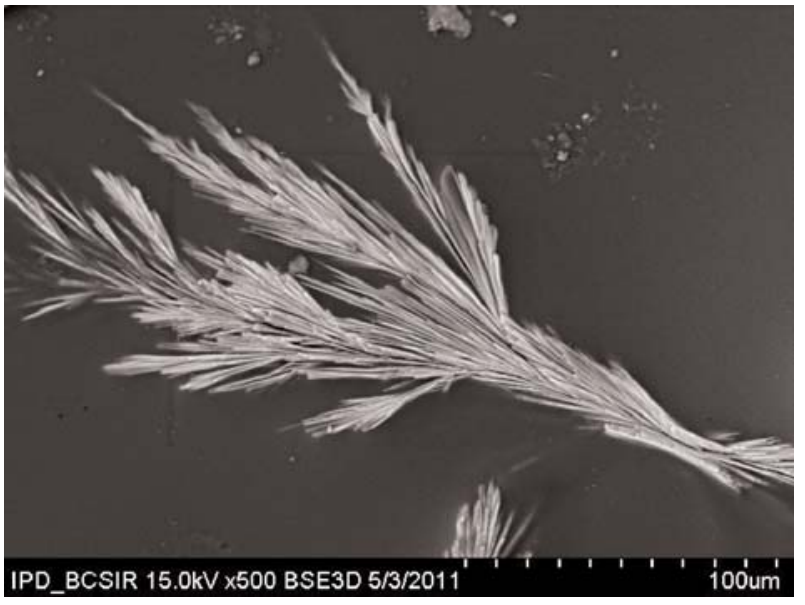

Fig. 3. SEM images of $\mathrm{PbCl}_{2}$

\section{Conclusion}

It can be concluded that re-crystallization is the vital step for the preparation of lead(II) chloride from galvanizing plant wastes containing lead, zinc and iron. Nearly 67 percent lead could be extracted and converted to lead(II) chloride having purity of nearly 93 percent. X-ray diffraction analysis confirmed that the product obtained posses cotunnite phase having orthorhombic structure. Scanning electron microscopy confirmed the needle like shape of the crystal produced.

\section{Acknowledgement}

The authors wish to thank BUET authorities; Md. Shahjan Siraz and Md. Shamim Ahmed, Analytical Research Division BCSIR Laboratories, Dhaka; Ms Nazia Khatun and Suravi Islam, Industrial Physics Division, BCSIR Laboratories, Dhaka; Md. Rakibul Islam, PP \& PDC, BCSIR for their heartiest co-operation for doing analyses.

\section{References}

Abdul Khadar M and Ittyachen MA (1980), J. Cryst. Growth 48, 149. en.wikipedia.org/wiki/ lead(II) chloride.

Kirk-Orthmer "Encyclopedia of Chemical Technology", John-Wiley Sons Inc. (1995). (Ed. 4). 15134.

Lohse J, Sander K and Wirts M (2008), Adaptation to Scientific and Technical Progress of Annex II Directive 2000/53/EC ,OKO-Institute.e.V (Final Report)

Nisha P and Santha Kumari, (2008), Characterization of lead(II) single crystals grown in silica gel"http//onlinelibrary.wiley.com/doi/10.1002/crat.200710 979/pdf .

Perry DL and Phillips SL (1995), Handbook of Inorganic Compounds, p 213.

Robert C Weast, "Handbook of Chemistry and Physics", 53rd edition, published by The Chemical Rubber Company, p B-101.

Sagayaraj P, Sivanesan S and Gobinathan R (1995), Cryst. Res. Technol. 30: 299, 425.

Thorpe JF and Whiteley MA (1946), Thorp's Dictionary of Applied Chemistry, 4th Edition VII 251.

Barbara Elvers, Stephen Hawkins and Gail Schulz, "Ullman's Encyclopedia of Industrial Chemistry", Fifth completely Revised Edition (1990), VCH Publishers (1990), A 15, 251.

Received: 01 February 2012; Revised: 04 June 2012; Accepted: 20 June 2012 . 